\title{
A SIMPLE EXPLANATION FOR THE UNFAVORABLE TAX TREATMENT OF INVESTMENT COSTS
}

\author{
PAOLO M. PANTEGHINI
}

CESIFO WORKING PAPER NO. 1784

CATEgORY 1: PUBLIC FINANCE

August 2006

An electronic version of the paper may be downloaded

- from the SSRN website:

- from the RePEc website:

www.SSRN.com

- from the CESifo website:

www.RePEc.org

www.CESifo-group.de 


\title{
A SIMPLE EXPLANATION FOR THE UNFAVORABLE TAX TREATMENT OF INVESTMENT COSTS
}

\begin{abstract}
The evidence shows that in most countries the present value of depreciation allowances is less than $100 \%$ of the cost of capital. In this article we use a real-option model with debt financing, and show that less favorable depreciation allowances are offset by tax benefits arising from debt financing. Allowing partial deduction of capital cost is thus a necessary condition for investment neutrality to hold.
\end{abstract}

JEL Code: D92, G33.

Keywords: capital structure, irreversibility, real options and taxation.

Paolo M. Panteghini

Department of Economics

University of Brescia

Via San Faustino 74/B

25122 Brescia

Italy

panteghi@eco.unibs.it

August 2, 2006

The author would like to thank Vesa Kanniainen and Carlo Scarpa for helpful comments. 


\section{Introduction}

According to standard analysis, investment neutrality requires full deduction of both investment costs and interest expenses. ${ }^{1}$ However, the available evidence (e.g. Devereux et al. (2002)) shows that, in most countries, the present value of depreciation allowances is usually less than $100 \%$ of the investment cost. This widespread phenomenon, illustrated in Figure 1, may then lead to the conclusion that current tax systems discourage investment.

A recent stream of literature has tried to explain this policy by means of optimal tax theory. In particular, Haufler and Schjelderup (2000) have shown that when foreign direct investments are allowed and firms can shift profits, it is optimal for the governments to allow the partial deductibility of investment costs. Becker and Fuest (2005) have found a similar result if mobile firms are more profitable than immobile firms.

It is worth noting that the above literature disregards the fact that firms' capital structure can be the optimal solution for a trade-off between costs and benefits of debt financing. ${ }^{2}$ In this article we provide a simple explanation for the apparently unfavorable tax treatment of investment costs by accounting for the fact that a significant portion of investment is usually debt financed. In particular, we apply a real-option model where the firm can decide not only whether but also when to invest. We will then show that, coeteris paribus, debt financing induces the firm to invest earlier in order to benefit from interest deductibility. As long as full deduction of interest expenses is allowed and firms can optimally choose their capital structure, therefore, less favorable depreciation allowances are offset by tax benefits arising from optimal leverage. This leads to the conclusion that partial deduction of capital cost is a necessary condition for investment neutrality to hold.

The structure of article is as follows. In section 2 we develop the model. In section 3 we analyze firms' decisions on the optimal capital structure and investment timing. Neutrality properties are finally discussed in section 4 .

\footnotetext{
${ }^{1}$ For instance Brown (1948, p. 537) argues that distortions "can be substantially eliminated by a system which permits the firm to deduct either (1) current outlays (or an average of outlays for a short period) on depreciable assets or (2) normal depreciation on total assets" (p.537). For further details on this literature see Stiglitz (1973) and Sinn (1987).

${ }^{2}$ For a survey on the literature dealing with tax-induced optimal capital structure see Graham (2003).
} 


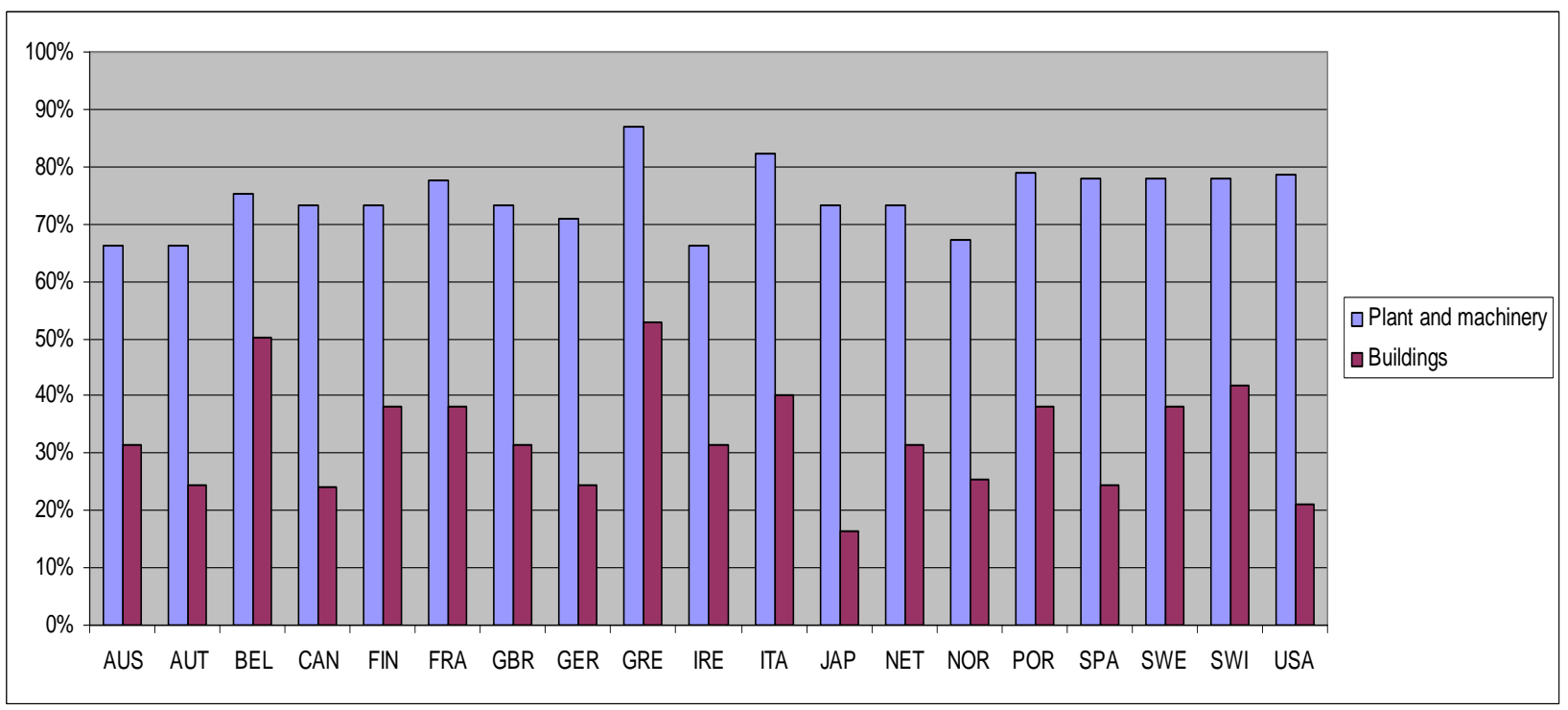

Figure 1: Present discounted value of depreciation allowances in industrialized countries (2005). Source: Klemm (2005) at http://www.ifs.org.uk/

\section{The model}

In this section we introduce a model describing the financial and investment strategies of a representative firm. We assume that the firm starts to earn a payoff $\Pi_{t}$ once an investment cost, denoted as $I$, has been paid. As time passes, depreciation entails that investment's productivity decreases or, equivalently, maintenance costs raise.

The firm's payoff evolves according to the following geometric Brownian motion

$$
d \Pi_{t}=\alpha \Pi_{t} d t+\sigma \Pi_{t} d z_{t}, \quad \text { with } \Pi_{0}>0,
$$

where $\alpha \equiv \alpha^{\prime}-\lambda$ is the expected rate of growth, that is given by the difference between the gross-of-depreciation growth rate $\alpha$ ' less the depreciation rate $\lambda$, which entails a gradual decrease in the project's profitability. Moreover, $\sigma$ and $d z_{t}$ are the instantaneous standard deviation and the increment of a standard Wiener process, respectively.

We assume that risk is fully diversifiable, credit markets are perfectly competitive, and information is symmetric. Moreover we assume that: 
Assumption 1 when the firm invests it can borrow some resources and pay a constant coupon $C \leq \Pi_{0}$, that cannot be renegotiated;

Assumption 2 default takes place when $\Pi_{t}$ drops to $C$;

Assumption 3 the cost of default is proportional to the coupon received, namely default cost $v C$ with $v>0$.

In line with Leland (1994), assumption 1 entails that the firm sets a coupon and then computes the market value of debt. In the absence of arbitrage, this is equivalent to first set the value of debt and, then, compute the effective interest rate under the non-arbitrage condition. For simplicity, we also assume that debt cannot be renegotiated. ${ }^{3}$

Assumptions 2 and 3 describe default. According to assumption 2 default occurs when the firm does not meet its debt obligation: in particular, default is triggered when the firm's payoff $\Pi$ falls to the exogenously given threshold point $C$. This means that debt is protected, since condition $\Pi=C$ is a collateral constraint. ${ }^{4}$ In the event of default, the firm is expropriated by the lender. According to assumption 3, expropriation causes the lender to face a sunk default cost, $v C$, that is proportional to the coupon paid. ${ }^{5}$

Let us next introduce taxation. With no loss of generality we assume that when the firm invests it immediately receives a tax rebate equal to $\tau \Omega I$, where $\tau$ is the relevant tax rate and $\Omega$ is the present value of depreciation. ${ }^{6}$ Moreover we assume that, in line with most existing systems, interest payments are fully deductible, so that the firm's tax base is $\left(\Pi_{t}-C\right)$. Finally we assume

\footnotetext{
${ }^{3}$ For an analysis of debt renegotiation see e.g. Goldstein et al. (2001).

${ }^{4}$ As pointed out by Leland (1994), minimum net-worth requirements, implied by protected debt, are common in short-term debt financing. It is worth noting that the quality of results would not change if we assumed that debt is unprotected. This kind of debt is more common in long-term debt financing and entails that default timing is optimally chosen by shareholders. For further details on default conditions see Smith and Warner (1977). For a study of corporate taxation under default risk see also Panteghini (2006).

${ }^{5}$ The quality of results does not change if we assume that the cost of default is proportional to the firm value, rather than to the debt value. For a detailed analysis of default costs see e.g. Branch (2002).

${ }^{6}$ Notice that the quality of results would not change if we assumed that fiscal depreciation allowances were deducted year by year. In this case, however, computations would be messy.
} 
that, before default, the lender is tax exempt. ${ }^{7}$ After default, however, she becomes shareholder and is thus subject to corporate taxation.

\section{The firms' decisions}

The firm's problem is thus one of choosing both the investment timing $(T \geq t)$ and the coupon $C^{8}$ by maximizing the present value of future after-tax cash flows, i.e.

$$
\max _{T>0, C>0} V\left(\Pi_{t} ; \bar{\Pi}, C\right)=E_{t}\left\{e^{-r(T-t)}\left(\int_{T}^{\infty}\left[(1-\tau)\left(\Pi_{s}-C\right)\right] e^{-r s} d s-(1-\Omega \tau) I\right)\right\},
$$

where $E_{t}\{$.$\} is the expectation operator and r$ is the exogenously given riskfree interest rate.

It is worth noting that the optimal investment time $T$ corresponds to a trigger point $\bar{\Pi}$. This means that whenever the current payoff reaches $\bar{\Pi}$, the firm invests. Omitting for simplicity the time variable, and defining $\Pi$ as the current payoff we can thus rewrite (2) as follows (see Appendix A):

$\max _{\bar{\Pi}>0, C>0} V(\Pi ; \bar{\Pi}, C)=\left(\frac{\Pi}{\bar{\Pi}}\right)^{\beta_{1}}\left[\frac{(1-\tau) \bar{\Pi}}{\delta}+\frac{C}{r}\left(\tau-(\tau+r \nu)\left(\frac{\bar{\Pi}}{C}\right)^{\beta_{2}}\right)-(1-\Omega \tau) I\right]$,

where $\delta \equiv r-\alpha{ }^{9}$ Solving (3) (see Appendix B) we obtain the optimal ratio between $C$ and $\bar{\Pi}$

$$
\frac{C}{\bar{\Pi}}=\left(\frac{1}{1-\beta_{2}} \cdot \frac{\tau}{\tau+r \nu}\right)^{-\frac{1}{\beta_{2}}}
$$

and the firm's trigger point

$$
\bar{\Pi}=\frac{\delta}{1+m(\tau)} \frac{\beta_{1}}{\beta_{1}-1} \frac{1-\Omega \tau}{1-\tau} I
$$

\footnotetext{
${ }^{7}$ Given that effective tax rates on capital income are fairly low, this simplifying assumption does not look unrealistic.

${ }^{8}$ The existence of a trade-off between default costs and tax benefits of debt financing induces the firm to choose the optimal value of $C$.

${ }^{9}$ The term $\delta$ is the so-called convenience (or dividend) yield, which must be positive in order for a solution to be obtained (see Dixit and Pindyck, 1994).
} 
with $m(\tau) \equiv \frac{\tau}{1-\tau} \frac{\delta}{r}\left(\frac{\beta_{2}}{\beta_{2}-1}\right)\left(\frac{1}{1-\beta_{2}} \cdot \frac{\tau}{\tau+r \nu}\right)^{-\frac{1}{\beta_{2}}}>0, \beta_{1}>1$, and $\beta_{2}<0$.

As shown in (4), the optimal ratio $\left(\frac{C}{\bar{\Pi}}\right)$ is positively related to $\tau$ and negatively related to the default cost parameter $v{ }^{10}$

Eq. (5) shows that the firm's investment timing depends on financial strategies. In particular the term $\frac{1}{1+m(\tau)}$ measures the leverage effect of debt financing on the firm's trigger point. Given $\frac{1}{1+m(\tau)}<1$, we can indeed state that debt financing induces the firm to invest earlier. The intuition behind this result is straightforward: if a firm can borrow, it will be stimulated to invest earlier in order to benefit from interest deductibility. We can thus say that full deductibility of interest expenses is equivalent "overinvestment" in a static framework. While the standard notion of "overinvestment" typically refers to the amount spent by the firm, in this context we can use the term overinvestment to define the situation where the expected value of investment at any given time is greater than the laissez-faire one. This result will then be used to address our policy implications in terms of neutrality.

\section{Investment neutrality}

Let us next explore under what conditions the corporation tax is neutral in terms of investment timing. To do so we first set $\tau=0$ and thus obtain the laissez-faire trigger point

$$
\Pi^{*} \equiv \frac{\beta_{1}}{\beta_{1}-1} \delta I
$$

It is worth noting that setting $\tau=0$ entails that the tax benefit of debt is null. In the absence of taxation, therefore, the optimal financial strategy is to use only equity finance. ${ }^{11}$

Given (6) we can say that investment timing is unaffected by taxation if the equality

$$
\bar{\Pi}=\Pi^{*}
$$

\footnotetext{
${ }^{10}$ This results are in line with the empirical evidence provided by Fan et al. (2003). For a detailed discussion on tax-induced debt financing see also Graham (2003).

${ }^{11}$ Notice that the quality of results would not change if we introduced non-tax benefits of debt financing (e.g. related to agency costs). In this case laissez-faire investment would be partially debt financed.
} 
holds. $^{12}$ If this is true taxation does not distort the investment decision. Substituting (5) and (6) into (7) we obtain

$$
\frac{1-\bar{\Omega} \tau}{1-\tau}=1+m(\tau)
$$

where $\bar{\Omega}$ is the value of $\Omega$ that ensures neutrality in terms of investment timing. Using (8) we know that $\frac{1-\bar{\Omega} \tau}{1-\tau}>1$. It is thus straightforward to show that investment timing is unaffected by taxation if the present value of fiscal depreciation allowances is

$$
\Omega=\bar{\Omega}<1 .
$$

This result provides a simple explanation for the apparently unfavorable tax treatment of investment. It is indeed shown that less favorable depreciation allowances compensate for tax benefits (and thus leverage effects) arising from debt. As long as full deduction of interest expenses is allowed and firms can optimally choose their capital structure, therefore, the present value of depreciation allowances must be less than $100 \%$ in order for investment timing not to be distorted.

\footnotetext{
${ }^{12}$ In line with Johansson (1969), we can say that condition (7) ensures an identical ranking in a pre-tax and in a post-tax profitability analysis. For further details on tax neutrality in a real-option setting see Niemann (1999), and Panteghini (2001).
} 


\section{A The computation of (3)}

To obtain (3) we must compute both the value of equity and the value of debt. Let us then define $E(\Pi ; C)$ as the market value of the equity. Following Leland (1994), we derive its contingent claim value as the solution of the following non-arbitrage condition ${ }^{13}$

$$
r E(\Pi ; C)=(1-\tau)(\Pi-C)+(r-\delta) \Pi E_{\Pi}(\Pi ; C)+\frac{\sigma^{2}}{2} \Pi^{2} E_{\Pi \Pi}(\Pi ; C) .
$$

Solving (9) one obtains

$$
E(\Pi ; C)= \begin{cases}0 & \text { after default } \\ (1-\tau)\left(\frac{\Pi}{\delta}-\frac{C}{r}\right)+\sum_{i=1}^{2} A_{i} \Pi^{\beta_{i}} & \text { before default }\end{cases}
$$

where $\delta \equiv r-\alpha$. Terms $\beta_{1}>1$ and $\beta_{2}<0$ are the roots of the characteristic equation $\Psi(\beta)=\frac{1}{2} \sigma^{2} \beta(\beta-1)+(r-\delta) \beta-r=0 .{ }^{14}$ Let us next compute the constants $A_{1}$ and $A_{2}$. In the absence of any financial bubbles, $A_{1}$ is nil. To compute $A_{2}$, notice that default occurs when $\Pi$ drops to $C$, namely the condition $E(C ; C)=0$ holds. ${ }^{15}$ Using this boundary condition we can thus rewrite (10) as

$$
E(\Pi ; C)= \begin{cases}0 & \text { after default } \\ (1-\tau)\left(\frac{\Pi}{\delta}-\frac{C}{r}\right)-(1-\tau)\left(\frac{C}{\delta}-\frac{C}{r}\right)\left(\frac{\Pi}{C}\right)^{\beta_{2}} & \text { before default }\end{cases}
$$

The value of debt, defined as $D(\Pi ; C)$, must satisfy the following nonarbitrage condition

$$
r D(\Pi ; C)=G+(r-\delta) \Pi D_{\Pi}(\Pi ; C)+\frac{\sigma^{2}}{2} \Pi^{2} D_{\Pi \Pi}(\Pi ; C),
$$

\footnotetext{
${ }^{13}$ For further details on mathematical steps see Panteghini (2006).

${ }^{14}$ These roots are $\beta_{1}=\frac{1}{2}-\frac{r-\delta}{\sigma^{2}}+\sqrt{\left(\frac{r-\delta}{\sigma^{2}}-\frac{1}{2}\right)^{2}+\frac{2 r}{\sigma^{2}}}>1$, and $\beta_{2}=\frac{1}{2}-\frac{r-\delta}{\sigma^{2}}-$ $\sqrt{\left(\frac{r-\delta}{\sigma^{2}}-\frac{1}{2}\right)^{2}+\frac{2 r}{\sigma^{2}}}<0$, respectively.

${ }^{15}$ Remember that we assumed that debt is protected. For a comparison with default under unprotected debt financing see Panteghini (2006).
} 
where $G=(1-\tau) \Pi, C$. The closed-form solution of (12) is:

$$
D(\Pi ; C)= \begin{cases}\frac{(1-\tau) \Pi}{\delta}+\sum_{i=1}^{2} B_{i} \Pi^{\beta_{i}} & \text { after default, } \\ \frac{C}{r}+\sum_{i=1}^{2} D_{i} \Pi^{\beta_{i}} & \text { before default. }\end{cases}
$$

To compute $B_{2}$ we use the boundary condition $D(0 ; C)=0$, which means that when $\Pi$ falls to zero the lender's post-default claim is nil. Thus we have $B_{2}=0$. In the absence of any financial bubble, moreover, we have $B_{1}=D_{1}=0$. Finally, to compute $D_{2}$ we let the pre-default branch of (13) meet with its after-default one, net of the default cost $v C$, at point $\Pi=C$, i.e.

$$
\frac{C}{r}+D_{2} C^{\beta_{2}}=\frac{(1-\tau) C}{\delta}-v C
$$

Solving (14) for $D_{2}$ and substituting into (13) thus yields

$$
D(\Pi ; C)= \begin{cases}\frac{(1-\tau) \Pi}{\delta} & \text { after default } \\ {\left[\frac{1}{r}+\left(\frac{1-\tau}{\delta}-\frac{1}{r}-v\right)\left(\frac{\Pi}{C}\right)^{\beta_{2}}\right] C} & \text { before default. }\end{cases}
$$

Let us next compute the value function. Using (11) and (15) we then obtain the firm's net present value

$$
\begin{aligned}
& W(\Pi ; C)=E(\Pi ; C)+D(\Pi ; C)-(1-\Omega \tau) I= \\
& =\frac{(1-\tau) \Pi}{\delta}+\frac{C}{r}\left[\tau-(\tau+r \nu)\left(\frac{\Pi}{C}\right)^{\beta_{2}}\right]-(1-\Omega \tau) I .
\end{aligned}
$$

Given (16) we can rewrite (2) as

$$
V(\Pi ; \bar{\Pi}, C)=E_{t}\left[e^{-r(T-t)}\right] \cdot W(\bar{\Pi} ; C) .
$$

Following Harrison (1985), it is easy to ascertain that $E_{t}\left[e^{-r(T-t)}\right]=\left(\frac{\Pi}{\bar{\Pi}}\right)^{\beta_{1}}$. Using (17) we thus obtain (3).

\section{B First order conditions}

The first order conditions of (3) are

$$
\frac{\partial V(\Pi ; \bar{\Pi}, C)}{\partial C}=\left(\frac{\Pi}{\bar{\Pi}}\right)^{\beta_{1}} \frac{1}{r}\left[\tau-\left(1-\beta_{2}\right)(\tau+r \nu)\left(\frac{\bar{\Pi}}{C}\right)^{\beta_{2}}\right]=0
$$




$$
\frac{\partial V(\Pi ; \bar{\Pi}, C)}{\partial \bar{\Pi}}=\left(\frac{\Pi}{\bar{\Pi}}\right)^{\beta_{1}}\left\{\left[\frac{(1-\tau)}{\delta}-\frac{\beta_{2}}{r}(\tau+r \nu)\left(\frac{\bar{\Pi}}{C}\right)^{\beta_{2}-1}\right]-\beta_{1} \frac{V(\Pi ; \bar{\Pi}, C)}{\bar{\Pi}}\right\}=0 .
$$

Rearranging (18) one easily obtains (4). Substituting (4) into (19) and rearranging thus yields (5). 


\section{References}

[1] Becker J. and C. Fuest (2005), Optimal Tax Policy when Firms are Internationally Mobile, CESifo Working Paper No. 1592.

[2] Branch, B. (2002), The Costs of Bankruptcy: A Review, International Review of Financial Analysis, 11, pp. 39-57.

[3] Brown E.C. (1948), Business-Income Taxation and Investment Incentives, in L.A. Meltzer, E.D. Domar et al., eds., Income, Employment and Public Policy, Essays in Honor of A.H. Hansen, W.W. Norton \& c., New York.

[4] Devereux, M.P., Griffith, R., and A. Klemm (2002), Corporate Income Tax Reforms and International Tax Competition, Economic Policy: A European Forum, October, v. 0, iss. 35, pp. 449-488.

[5] Dixit, A. and R.S. Pindyck (1994), Investment under Uncertainty, Princeton University Press.

[6] Fan, J.P.H., S. Titman, and G.J. Twite (2003), An International Comparison of Capital Structure and Debt Maturity Choices, AFA 2005 Philadelphia Meetings, EFA 2003 Annual Conference Paper No. 769.

[7] Goldstein, R., N. Ju and H. Leland (2001), An EBIT-Based Model of Dynamic Capital Structure, Journal of Business, 74, pp. 483-512.

[8] Graham J.R. (2003), Taxes and Corporate Finance: A Review, Review of Financial Studies, 16, pp. 1075-1129.

[9] Harrison J.M., (1985), Brownian Motion and Stochastic Flow Systems, John Wiley \& Sons, New York.

[10] Haufler A. and G. Schjelderup (2000), Corporate Tax Systems and Cross Country Profit Shifting, Oxford Economic Papers, 52, pp. 306-325.

[11] Johansson S.-E. (1969), Income Taxes and Investment Decisions, Swedish Journal of Economics, 71, pp. 104-110.

[12] Leland H.E. (1994), Corporate Debt Value, Bond Covenants, and Optimal Capital Structure, Journal of Finance, September, 49, iss. 4, pp. 1213-52. 
[13] Niemann R. (1999), Neutral Taxation under Uncertainty - a Real Option Approach, FinanzArchiv, 56, pp. 51-66.

[14] Panteghini P.M. (2001), Corporate Tax Asymmetries under Investment Irreversibility, FinanzArchiv, 58, pp. 207-226.

[15] Panteghini, P.M. (2006), S-Based Taxation under Default Risk, Journal of Public Economics, forthcoming.

[16] Sinn H.W. (1987), Capital Income Taxation and Resource Allocation, North-Holland, Amsterdam.

[17] Smith C.W., Jr., and J.B. Warner (1977), Bankruptcy, Secured Debt, and Optimal Capital Structure: Comment, Journal of Finance, 34, pp. $247-51$.

[18] Stiglitz J.E. (1973), Taxation, Corporate Financial Policy, and the Cost of Capital, Journal of Public Economics, 2, pp. 1-34. 


\section{CESifo Working Paper Series}

(for full list see www.cesifo-group.de)

1720 Ronald McKinnon and Gunther Schnabl, China's Exchange Rate and International Adjustment in Wages, Prices, and Interest Rates: Japan Déjà Vu?, May 2006

1721 Paolo M. Panteghini, The Capital Structure of Multinational Companies under Tax Competition, May 2006

1722 Johannes Becker, Clemens Fuest and Thomas Hemmelgarn, Corporate Tax Reform and Foreign Direct Investment in Germany - Evidence from Firm-Level Data, May 2006

1723 Christian Kleiber, Martin Sexauer and Klaus Waelde, Bequests, Taxation and the Distribution of Wealth in a General Equilibrium Model, May 2006

1724 Axel Dreher and Jan-Egbert Sturm, Do IMF and World Bank Influence Voting in the UN General Assembly?, May 2006

1725 Swapan K. Bhattacharya and Biswa N. Bhattacharyay, Prospects of Regional Cooperation in Trade, Investment and Finance in Asia: An Empirical Analysis on BIMSTEC Countries and Japan, May 2006

1726 Philippe Choné and Laurent Linnemer, Assessing Horizontal Mergers under Uncertain Efficiency Gains, May 2006

1727 Daniel Houser and Thomas Stratmann, Selling Favors in the Lab: Experiments on Campaign Finance Reform, May 2006

1728 E. Maarten Bosker, Steven Brakman, Harry Garretsen and Marc Schramm, A Century of Shocks: The Evolution of the German City Size Distribution 1925 - 1999, May 2006

1729 Clive Bell and Hans Gersbach, Growth and Enduring Epidemic Diseases, May 2006

1730 W. Bentley MacLeod, Reputations, Relationships and the Enforcement of Incomplete Contracts, May 2006

1731 Jan K. Brueckner and Ricardo Flores-Fillol, Airline Schedule Competition: ProductQuality Choice in a Duopoly Model, May 2006

1732 Kerstin Bernoth and Guntram B. Wolff, Fool the Markets? Creative Accounting, Fiscal Transparency and Sovereign Risk Premia, May 2006

1733 Emmanuelle Auriol and Pierre M. Picard, Government Outsourcing: Public Contracting with Private Monopoly, May 2006

1734 Guglielmo Maria Caporale and Luis A. Gil-Alana, Modelling Structural Breaks in the US, UK and Japanese Unemployment Rates, May 2006 
1735 Emily J. Blanchard, Reevaluating the Role of Trade Agreements: Does Investment Globalization Make the WTO Obsolete?, May 2006

1736 Per Engström and Bertil Holmlund, Tax Evasion and Self-Employment in a High-Tax Country: Evidence from Sweden, May 2006

1737 Erkki Koskela and Mikko Puhakka, Cycles and Indeterminacy in Overlapping Generations Economies with Stone-Geary Preferences, May 2006

1738 Saku Aura and Thomas Davidoff, Supply Constraints and Housing Prices, May 2006

1739 Balázs Égert and Ronald MacDonald, Monetary Transmission Mechanism in Transition Economies: Surveying the Surveyable, June 2006

1740 Ben J. Heijdra and Ward E. Romp, Ageing and Growth in the Small Open Economy, June 2006

1741 Robert Fenge and Volker Meier, Subsidies for Wages and Infrastructure: How to Restrain Undesired Immigration, June 2006

1742 Robert S. Chirinko and Debdulal Mallick, The Elasticity of Derived Demand, Factor Substitution and Product Demand: Corrections to Hicks' Formula and Marshall's Four Rules, June 2006

1743 Harry P. Bowen, Haris Munandar and Jean-Marie Viaene, Evidence and Implications of Zipf's Law for Integrated Economies, June 2006

1744 Markku Lanne and Helmut Luetkepohl, Identifying Monetary Policy Shocks via Changes in Volatility, June 2006

1745 Timo Trimborn, Karl-Josef Koch and Thomas M. Steger, Multi-Dimensional Transitional Dynamics: A Simple Numberical Procedure, June 2006

1746 Vivek H. Dehejia and Yiagadeesen Samy, Labor Standards and Economic Integration in the European Union: An Empirical Analysis, June 2006

1747 Carlo Altavilla and Paul De Grauwe, Forecasting and Combining Competing Models of Exchange Rate Determination, June 2006

1748 Olaf Posch and Klaus Waelde, Natural Volatility, Welfare and Taxation, June 2006

1749 Christian Holzner, Volker Meier and Martin Werding, Workfare, Monitoring, and Efficiency Wages, June 2006

1750 Steven Brakman, Harry Garretsen and Charles van Marrewijk, Agglomeration and Aid, June 2006

1751 Robert Fenge and Jakob von Weizsäcker, Mixing Bismarck and Child Pension Systems: An Optimum Taxation Approach, June 2006 
1752 Helge Berger and Michael Neugart, Labor Courts, Nomination Bias, and Unemployment in Germany, June 2006

1753 Chris van Klaveren, Bernard van Praag and Henriette Maassen van den Brink, A Collective Household Model of Time Allocation - a Comparison of Native Dutch and Immigrant Households in the Netherlands, June 2006

1754 Marko Koethenbuerger, Ex-Post Redistribution in a Federation: Implications for Corrective Policy, July 2006

1755 Axel Dreher, Jan-Egbert Sturm and Heinrich Ursprung, The Impact of Globalization on the Composition of Government Expenditures: Evidence from Panel Data, July 2006

1756 Richard Schmidtke, Private Provision of a Complementary Public Good, July 2006

1757 J. Atsu Amegashie, Intentions and Social Interactions, July 2006

1758 Alessandro Balestrino, Tax Avoidance, Endogenous Social Norms, and the Comparison Income Effect, July 2006

1759 Øystein Thøgersen, Intergenerational Risk Sharing by Means of Pay-as-you-go Programs - an Investigation of Alternative Mechanisms, July 2006

1760 Pascalis Raimondos-Møller and Alan D. Woodland, Steepest Ascent Tariff Reforms, July 2006

1761 Ronald MacDonald and Cezary Wojcik, Catching-up, Inflation Differentials and Credit Booms in a Heterogeneous Monetary Union: Some Implications for EMU and new EU Member States, July 2006

1762 Robert Dur, Status-Seeking in Criminal Subcultures and the Double Dividend of ZeroTolerance, July 2006

1763 Christa Hainz, Business Groups in Emerging Markets - Financial Control and Sequential Investment, July 2006

1764 Didier Laussel and Raymond Riezman, Fixed Transport Costs and International Trade, July 2006

1765 Rafael Lalive, How do Extended Benefits Affect Unemployment Duration? A Regression Discontinuity Approach, July 2006

1766 Eric Hillebrand, Gunther Schnabl and Yasemin Ulu, Japanese Foreign Exchange Intervention and the Yen/Dollar Exchange Rate: A Simultaneous Equations Approach Using Realized Volatility, July 2006

1767 Carsten Hefeker, EMU Enlargement, Policy Uncertainty and Economic Reforms, July 2006 
1768 Giovanni Facchini and Anna Maria Mayda, Individual Attitudes towards Immigrants: Welfare-State Determinants across Countries, July 2006

1769 Maarten Bosker and Harry Garretsen, Geography Rules Too! Economic Development and the Geography of Institutions, July 2006

1770 M. Hashem Pesaran and Allan Timmermann, Testing Dependence among Serially Correlated Multi-category Variables, July 2006

1771 Juergen von Hagen and Haiping Zhang, Financial Liberalization in a Small Open Economy, August 2006

1772 Alessandro Cigno, Is there a Social Security Tax Wedge?, August 2006

1773 Peter Egger, Simon Loretz, Michael Pfaffermayr and Hannes Winner, Corporate Taxation and Multinational Activity, August 2006

1774 Jeremy S.S. Edwards, Wolfgang Eggert and Alfons J. Weichenrieder, The Measurement of Firm Ownership and its Effect on Managerial Pay, August 2006

1775 Scott Alan Carson and Thomas N. Maloney, Living Standards in Black and White: Evidence from the Heights of Ohio Prison Inmates, 1829 - 1913, August 2006

1776 Richard Schmidtke, Two-Sided Markets with Pecuniary and Participation Externalities, August 2006

1777 Ben J. Heijdra and Jenny E. Ligthart, The Transitional Dynamics of Fiscal Policy in Small Open Economies, August 2006

1778 Jay Pil Choi, How Reasonable is the 'Reasonable' Royalty Rate? Damage Rules and Probabilistic Intellectual Property Rights, August 2006

1779 Ludger Woessmann, Efficiency and Equity of European Education and Training Policies, August 2006

1780 Gregory Ponthiere, Growth, Longevity and Public Policy, August 2006

1781 Laszlo Goerke, Corporate and Personal Income Tax Declarations, August 2006

1782 Florian Englmaier, Pablo Guillén, Loreto Llorente, Sander Onderstal and Rupert Sausgruber, The Chopstick Auction: A Study of the Exposure Problem in Multi-Unit Auctions, August 2006

1783 Adam S. Posen and Daniel Popov Gould, Has EMU had any Impact on the Degree of Wage Restraint?, August 2006

1784 Paolo M. Panteghini, A Simple Explanation for the Unfavorable Tax Treatment of Investment Costs, August 2006 